\title{
GAMBARAN TINGKAT DEPRESI PADA LANJUT USIA DI WILAYAH KERJA PUSKESMAS PARONGPONG
}

\author{
DEPRESSION DESCRIPTION LEVELS ON OLD AGE IN THE WORK AREA \\ OF PARONGPONG PUBLIC HEALTH CENTER
}

\author{
Jeanny Rantung \\ Fakultas IImu Keperawatan, Universitas Advent Indonesia \\ E-mail: Jeannyrantung@unai.edu
}

\begin{abstract}
ABSTRAK
Lanjut usia atau disebut juga lansia adalah proses alami yang terjadi dalam tahap pertumbuhan dan perkembangan setiap orang. Sejalan dengan bertambah usia, lansia akan mengalami mengalami penurunan secara fisik, biologis, sosial maupun psikologis. Depresi adalah salah satu masalah yang dapat terjadi pada lansia karena penurunan psikomotor dan kognitif. Penelitian ini bertujuan untuk mengidentifikasi tingkat depresi lansia, dengan menggunakan metode deskriptif. Sampel yang digunakan adalah purposive sampling melibatkan 48 orang lansia yang berada di wilayah kerja Puskesmas Parongpong. Penelitian ini menggunakan Geriatric Depression Scale dengan 15 pertanyaan untuk mengukur tingkat depresi lansia. Data dianalisis dengan menggunakan distribusi frekwensi dan persentasi. Hasil penelitian menunjukkan lansia mengalami depresi sebanyak 30 orang lansia atau $62.5 \%$. Saran yang dapat diberikan untuk perawat adalah memberikan promosi kesehatan melalui penyuluhan maupun konseling tentang penanganan dan pencegahan terhadap depresi kepada lansia dan keluarga.
\end{abstract}

Kata Kunci: Depresi, Lansia, Tingkat depresi

\section{ABSTRACT}

Elderly is a natural process that occurs in the stages of growth and development of each person. Getting older will experience decreased in physical, biological, social and psychological. Depression is one of the problems that can occur in the elderly due to psychomotor and cognitive decreased. This study aims to identify the level of depression in the elderly, using descriptive methods. The sample used was purposive sampling involving 48 elderly people in the working area of the Parongpong Community Health Center. This study was using the Geriatric Depression Scale with 15 questions to measure the level of depression in the elderly. Data were analyzed using frequency distribution. The results showed that 30 elderlies (62.5\%) experience depression. Advice that can be given to nurses is to provide health promotion through counseling about the management and prevention of depression to the elderly and families.

Keywords: Elderly, Depression, Depression level

JURNAL

\section{SKOLASTIK}

\section{KEPERAWATAN}

VOL. 5, NO. 2

Juli - Desember 2019

ISSN: $2443-0935$

E-ISSN 2443 - 16990 


\section{PENDAHULUAN}

Lanjut usia (lansia) adalah suatu kejadian yang tidak dapat dicegah oleh siapapun karena setiap tahun terjadi penambahan umur dan pasti dialami oleh semua orang yang dikarunia umur panjang. Departemen Kesehatan (2009) membuat kategori usia sebagai berikut: lansia awal (46-55 tahun), lansia akhir (56-65 tahun), dan manula ( $>65$ tahun). Indonesia merupakan salah satu negara berkembang yang akan mengalami peningkatan jumlah penduduk lansia (Kemenkes RI, 2013). Populasi lansia terus mengalami peningkatan berdasarkan data proyeksi penduduk diperkirakan tahun 2017 terdapat 23,66 juta jiwa penduduk lansia di Indonesia $(9,03 \%)$. Diprediksi jumlah penduduk lansia tahun 2020 (27,08 juta), tahun 2025 (33,69 juta), tahun 2030 (40,95 juta) dan tahun 2035 (48,19 juta). (Kemenkes RI Pusdatin, 2017). Menurut Badan Pusat Statistik Jawa Barat (2017). Jumlah penduduk lansia di Jawa Barat pada tahun 2017 sebanyak 4.16 juta jiwa

Peningkatan jumlah lansia setiap tahun membutuhkan perhatian dan penanganan yang serius karena lansia mengalami penurunan secara fisik, biologis maupun psikis yang berhubungan erat dengan masalah ekonomi, sosial dan budaya. Perubahan sosial yang terjadi pada lansia adalah penurunan kognitif dan psikomotor. Penurunan kedua fungsi tersebut menyebabkan lansia mengalami aspek psikososial yang berkaitan dengan kepribadian lansia sedangkan perubahan psikologis yang terjadi pada lansia meliputi memori jangka pendek, frustasi, kesepian, ketakutan, kematian, depresi, dan kecemasan (Rohmawati, 2017).

Depresi merupakan gangguan mental yang menunjukkan gejala: mood tertekan, kehilangan kesenangan atau minat, perasaan bersalah atau harga diri rendah dan kepercayaan diri berkurang, gangguan makan atau tidur, kurang energi, dan konsentrasi yang menurun. Perubahan peran dan penurunan interaksi sosial serta kehilangan pekerjaan dapat menyebabkan lansia rentan terhadap masalah-masalah mental termasuk depresi (Pocklinton, 2017).

Menurut World Organization Health (WHO, 2012), depresi adalah gangguan mental umum yang ditandai dengan suasana yang tertekan, perasaan bersalah atau harga diri rendah, terjadi gangguan tidur dan makan, kehilangan kesenangan atau minat, merasa kurang energi serta konsentrasi rendah. Lebih lanjut WHO melaporkan bahwa 4.4\% populasi dunia atau lebih dari 300 juta orang diperkirakan menderita depresi (WHO, 2017). Di Indonesia, berdasarkan data yang didapat dari Pusat Informasi Penyakit Tidak Menular terdapat $11.6 \%$ lansia yang mengalami depresi (Kemenkes, 2012). Hasil lain didapat dari Riset Kesehatan Dasar (2013), menyebutkan prevalensi lansia berusia 55-64 tahun yang mengalami depresi adalah $15.9 \%$, lansia usia 65-74 tahun sebesar 23.2\% dan untuk lansia usia diatas 75 tahun terdapat sebesar $33.7 \%$.

Depresi yang dialami lansia dikenal juga sebagai late life depression, lansia rentan terhadap depresi yang disebabkan oleh faktor internal maupun eksternal. Faktor-faktor predisposisi 
yang menjadi resiko bagi lansia untuk mengalami depresi adalah kehilangan pekerjaan, pasangan, penghasilan dan dukungan sosial sejalan dengan bertambahnya usia (Soejono, 2006)

Berdasarkan uraian diatas, peneliti tertarik untuk mendapatkan data gambaran lansia yang mengalami depresi di wilayah kerja Puskesmas Parongpong Bandung Barat.

\section{METODE}

Penelitian ini adalah penelitian kuantitatif, desain penelitian deskriptif dengan pendekatan cross sectional, sampel penelitian adalah lansia yang berada di Desa Karyawangi RT 03 RW 9 Kecamatan Parongpong Bandung Barat dan tehnik pengambilan sampel adalah purposive sampel. Penelitian dilakukan dari bulan Oktober 2018 Januari 2019. Sampel yang terkumpul sebanyak 48 lansia dengan kriteria inklusi: lansia wanita berusia diatas 45 tahun, bersedia menjadi responden, dapat membaca dan menulis, tidak mengalami gangguan penglihatan dan pendengaran, tidak mengalami Alzheimer. Instrumen yang digunakan dalam penelitian ini adalah kuesioner Geriatric Depression Scale dengan 15 pertanyaan yang dikutip dari Kemenkes RI (2017). Masing-masing pertanyaan dapat dijawab dengan "ya" atau "tidak" yang akan memberikan satu poin untuk salah satu jawaban tersebut. Terdapat 5 pertanyaan positif yaitu item nomor 1 , 5, 7, 11, dan 13 apabila dijawab "ya" = 0 , "tidak" $=1$. Pertanyaan negatif sebanyak 10 item pertanyaan yaitu nomor 2, 3, 4, 6, 8, 9, 10, 12, 14, dan 15 apabila dijawab "ya" $=1$, "tidak" $=0$. Kemudian semua poin akan dijumlahkan dan diinterpretasikan dengan skor 0-4 menunjukkan tidak depresi, $5-8$ depresi ringan, 9-11 depresi sedang dan bila skor 12 - 15 menunjukkan depresi berat Data yang terkumpul kemudian dianalisis secara deskriptif dengan menggunakan program excel. Data dianalisis secara deskriptif untuk mengetahui sosiodemografi responden serta tingkat depresi responden.

\section{HASIL}

Berdasarkan data tabel 1, karakteristik lansia mayoritas berusia lebih dari 66 tahun sebanyak 24 orang (50\%) dan 23 orang berusia antara 56-65 tahun (47.9\%). Mayoritas tingkat pendidikan Dasar sebanyak 37 orang $(77.1 \%)$ diikuti oleh pendidikan Menengah 7 orang $(14.6 \%)$ dan pendidikan Tinggi sebanyak 4 orang $(8.3 \%)$. Responden yang menikah ( pasangan masih hidup) ada 36 orang $(75 \%)$ dan janda sebanyak 12 orang $(75 \%)$, mayoritas responden tidak bekerja sebanyak 43 orang atau $89.6 \%$

Tabel 1. Karakteristik Sosiodemografi Responden $(n=48)$

\begin{tabular}{lll}
\hline Karakteristik & Frekwensi & $\%$ \\
\hline Usia & & \\
$45-55$ tahun & 1 & 2.1 \\
$56-65$ tahun & 23 & 47.9 \\
$\quad$ 66 tahun & 24 & 50 \\
\hline Tingkat Pendidikan & & \\
$\quad$ Dasar & 37 & 77.1 \\
Menengah & 7 & 14.6 \\
$\quad$ Tinggi & 4 & 8.3 \\
\hline Status Pernikahan & & \\
$\quad$ Menikah & 36 & 75 \\
$\quad$ Janda/Tidak & 12 & 25 \\
Menikah & & \\
\hline Status Pekerjaan & & \\
$\quad$ Bekerja & 5 & 10.4 \\
Tidak Bekerja & 43 & 89.6 \\
\hline
\end{tabular}


Tabel 2. Distribusi Status Depresi $(n=48)$

\begin{tabular}{lll}
\hline $\begin{array}{l}\text { Tingkat } \\
\text { Depresi }\end{array}$ & Frekwensi & $\%$ \\
\hline Normal & 18 & 37.5 \\
$\begin{array}{l}\text { Depresi } \\
\text { Ringan }\end{array}$ & 16 & 33.3 \\
Depresi & 8 & 16.7 \\
Sedang & 6 & 12.5 \\
Depresi Berat & 6 & 100 \\
\hline Jumlah & 48 & \\
\hline
\end{tabular}

Pada Tabel 2 distribusi status dapresi menunjukkan ada 18 orang (37.5\%) tidak depesi, sebanyak 16 orang (33.3\%) mengalami depresi ringan, 8 orang $(16.7 \%)$ mengalami depresi sedang, dan 6 orang $(12.5 \%)$ mengalami depresi berat

\section{PEMBAHASAN}

Hasil penelitian menunjukkan bahwa lansia wanita di Desa Karyawangi RT 3 RW 9 Kecamatan Parongpong Bandung Barat mayoritas berada pada rentang usia 56 tahun sampai dengan > 66 tahun dengan usia terbanyak adalah $>66$ tahun. Proses penuaan yang terjadi pada lansia tidak dapat dihindari, dimana terjadi penurunan berbagai fungsi organ-organ tubuh karena proses menua menyebabkan kerusakan sel-sel, sehingga terjadi penurunan imunitas tubuh (Maryam, 2008). Berdasarkan data Badan Pusat Statisik (2013), persentase penduduk lansia usia $>60$ tahun berkisar $8.05 \%$, usia 70 tahun keatas sebesar $3.15 \%$ dan usia 80 tahun keatas sebesar $0.85 \%$.

Responden seluruhnya adalah wanita karena menurut Kemenkes RI (2013) angka harapan hidup pada perempuan lebih tinggi dibandingkan dengan lakilaki. Perubahan biologis pada pada wanita terutama faktor hormonal serta psikososial memiliki peranan penting yang harus dialami, sehingga menjadi stressor dan pemicu terjadinya depresi. Pemulihan depresi paling lambat karena perempuan dalam menghadapi masalah apapun menggunakan perasaan (Azizah, 2011; Mitchell, 2013)

Berkaitan dengan tingkat pendidikan, sebagian besar lansia (77.1\%) berada pada tingkat pendidikan rendah atau berada pada jenjang pendidikan SD, SMP atau bentuk lain yang sederajat. Berdasarkan data Kemenkes RI (2016) menunjukkan sebagian besar kelompok lansia di Indonesia cenderung tingkat pendidikannya rendah, lansia berpendidikan SD kebawah sekitar $70 \%$, tidak pernah menempuh SD sebanyak $38.06 \%$, tidak tamat SD sebanyak $28.76 \%$ dan sisanya adalah lansia yang tidak menyelesaikan SD. Stewart (2014) dalam bukunya mengutip Teori Beck et al, menjelaskan bahwa secara umum diketahui bahwa pendidikan merupakan hal yang penting dalam pengembangan kognitif, merupakan mediator suatu kejadian dan mood, sehingga pendidikan yang kurang dapat menjadi penyebab depresi pada lansia. Pendidikan dapat mempengaruhi perilaku seseorang, semakin tinggi pendidikan seseorang maka akan mudah untuk menerima informasi, sebaliknya dengan pendidikan yang rendah dapat menyebabkan kesulitan dalam menerima informasi dan menyelesaikan masalah, hal ini dapat 
menjadi faktor resiko terjadinya depresi.

Hasil penelitian menunjukkan status pernikahan yang masih mempunyai pasangan sebanyak 36 orang $(75 \%)$ dan yang berstatus janda 12 orang (25\%). Penelitian yang dilakukan oleh Livana, Susanti, Darwati dan Anggreani (2018) menunjukkan bahwa sebanyak 68 atau $60.2 \%$ lansia masih mempunyai pasangan, sebanyak 20 lansia atau 17.7 berstatus janda dan sisanya adalah duda.

Berdasarkan status pekerjaan, ditemukan sebanyak 43 orang $(89.6 \%)$ tidak bekerja dalam hal ini mengurus rumah tangga atau tinggal saja di rumah, sisanya sebanyak 5 orang (10.4\%) bekerja, ada yang bekerja di kebun atau menjaga warung. Lebih lanjut Santrock (2013) mengemukakan bahwa lansia yang banyak melakukan aktivitas dan terlibat dalam berbagai kegiatan kemungkinan untuk mengalami kesepian semakin kecil tetapi semakin besar kemungkinan untuk merasa puas dengan kehidupannya. Kegiatan yang banyak dilakukan lansia akan membantu melupakan perasaan-perasaan negatif, seperti: kehilangan dan kesepian karena kehilangan pasangan hidup. Menurut Jacoby, Oppenheimer dan Tom (2008), yang mengatakan bahwa pada pasangan yang menikah, wanita cenderung menderita depresi lebih banyak dibanding pria, namun lansia yang tidak memiliki pasangan akan lebih banyak mengalami depresi. Secara psikologis keadaan tersebut menunjukkan bahwa lansia wanita lebih mampu menghadapi kesendiriannya dibandingkan lansia pria.

Hasil penelitian menunjukkan bahwa lansia wanita di Desa Karyawangi RT 3 RW 9 Kecamatan Parongpong Bandung Barat sebanyak 18 orang (37.5\%) tidak mengalami depesi, yang mengalami depresi ringan sebanyak 16 orang (33.3\%), depresi sedang 8 orang (16.7\%), dan yang mengalami depresi berat sebanyak 6 orang (12.5\%). Temuan ini menunjukkan persentase tingkat depresi yang cukup tinggi pada lansia wanita, hasil ini sejalan dengan penelitian Livana, Susanti, Darwati dan Anggreani (2018) yang menunjukkan sebanyak $50 \%$ lansia wanita mengalami depresi ringan. Hasil penelitian ini juga selaras dengan artikel review yang dibuat oleh Pocklington (2017) bahwa insidensi dan prevalensi terjadinya depresi lebih besar pada wanita diatas usia 65 tahun yaitu sebanyak 10,4\%. Lebih lanjut dikatakan bahwa wanita yang lebih tua lebih cenderung mengalami episode depresi berulang, namun harus diakui bahwa perempuan mungkin lebih sering untuk datang ke layanan kesehatan dan mencari bantuan. Penelitian lain yang dilakukan di Cina oleh Liu et al (2018) menunjukkan bahwa prevalensi gejala depresi pada wanita dua kali lebih banyak (5.6\%) dibandingkan pada pria (2.4\%).

Menurut Ahmed dan Hamoud (2016) depresi yang dialami oleh lansia wanita adalah berdampak terjadinya kelebihan sekresi corticotropin-releasing hormone karena hiperaktivitashypothalamic-pituitary-adrenal axis (HPA-axist) yang berdampak terhadap episode depresi. Peningkatan kortisol 
menyebabkan ketidakseimbangan neurotransmitter utama, yaitu norepineprin, serotonin dan dopamine. Beberapa penelitian menunjukkan bahwa penurunan serotonin menjadi faktor pencetus depresi, pada beberapa pasien yang melakukan bunuh diri ditemukan serotonin yang rendah. Norepineprin berperan dalam patofisiologi depresi, karena memiliki fungsi kesiagaan tubuh, perhatian, energi, motivasi, penghargaan, kesenangan dan beberapa hal yang menarik dalam tubuh (Kaplan \& Saddock, 2010).

Lebih lanjut Kaplan dan Saddock (2010) menambahkan faktor yang dapat menyebabkan depresi adalah faktor sosial, yaitu hilangnya peranan sosial, hilangnya otonomi, kematian teman atau sanak saudara, penurunan kesehatan, peningkatan isolasi diri, keterbatasan finansial serta penurunan fungsi kognitif. Mauk (2010) menambahkan kondisi menua disertai dengan penyakit, kondisi psikososial terganggu akibat kehilangan akan menimbulkan konsekwensi fungsional negative, dimana terjadi gangguan selfesteem yang dapat mengakibatkan depresi.

\section{KESIMPULAN}

Berdasarkan hasil penelitian ditemukan bahwa lansia wanita di Desa Karyawangi RT 3 RW 9 Kecamatan Parongpong Bandung Barat yang mengalami depresi ringan sebanyak 16 orang $(33.3 \%)$, depresi sedang 8 orang (16.7\%), dan yang mengalami depresi berat sebanyak 6 orang $(12.5 \%)$, sedangkan sisanya 18 orang $(37.5 \%)$ tidak mengalami depresi. Responden berusia lebih dari 56 tahun, mayoritas tingkat pendidikan responden adalah SMP (72.9\%), responden yang menikah $(75 \%)$ dan mayoritas tidak bekerja $(89.6 \%)$.

\section{SARAN}

Perawat dalam memberikan asuhan keperawatan pada lansia dengan depresi diharapkan dapat bekerjasama dengan Puskesmas, melakukan pembinaan atau kegiatan yang melibatkan keluarga dan lingkungan dalam penanganan depresi pada lansia. Perawat dapat memberikan pemahaman dalam bentuk promosi kesehatan melalui penyuluhan maupun konseling tentang penanganan depresi dan pencegahannya kepada lansia dan keluarga.

\section{DAFTAR PUSTAKA}

Ahmed, B.M., Hamoud, H.J. (2016). Relationship Between Depression and Diabetes Mellitus. Diyala Journal of Medicine. 10 (1). 3236.

Azizah, L.M. (2011). Keperawatan lanjut usia. Yogyakarta: Graha Ilmu.

Badan Pusat Statistik. (2013). Statistik Penduduk Lanjut Usia. http://www.bps.go.id/webbeta/w ebsite/flipping_publikasi/stat_lan sia_2013/indexFlip.php

Badan Pusat Statistik Jawa Barat (2017). Profil Lansia Provinsi Jawa Barat 2017. http://www.jabar.bps.go.id 
Depkes RI. (2009). Profil Kesehatan Indonesia Tahun 2009. http://www.depkes.go.id/resourc es/download/pusdatin/profilkesehatan-indonesia/profilkesehatan-indonesia-2009.pdf

Jacoby, R., Oppenheimer, C., Tom, D. (2008). Oxford Textbook of Old Age Psychiatry. New York: Oxford University Press

Kaplan, H.I., Saddock, B.J. (2010). Sinopsis Psikiatri. Jilid 2. Terjemahan Widjaja Kusuma. Jakarta: Binarupa.

Kementrian Kesehatan Republik Indonesia. (2012). Data dan Informasi Kesehatan Penyakit Tidak Menular. Buletin

Kementrian Kesehatan Republik Indonesia. (2013). Buletin Jendela Data dan Informasi Kesehatan. Semester 1 . http://www.depkes.go.id/downlo ad.php?file=download/pusdatin/b uletin/buletin-lansia.pdf

Kementrian Kesehatan Republik Indonesia. (2016). Profil Kesehatan Indonesia Tahun 2015. http://www.depkes.go.id/resourc es/download/pusdatin/profilkesehatan-indonesia/profilkesehatan-Indonesia-2015.pdf

Kementrian Kesehatan Republik Indonesia. (2017). Sehat Jiwa. http://sehatjiwa.kemkes.go.id/deteksi_dini/d eskripsi/16
Liu, Q., Cai, H., Yang, L.H., Xiang, Y.B., Yang, G., Li, H., Gao, Y.T., Zheng, W., Susser, E., Shu, X.O. (2018). Depressive Symptoms and their association with social determinants and chronic diseases in middle-aged and elderly Chinese people. Scientific Reports, 8, 3841 (2018).

Livana, P.H., Susanti, Y., Darwati, L.E., Anngreani, R. (2018). Gambaran Tingkat Depresi Lansia. Nurscope. Jurnal Keperawatan Pemikiran Ilmiah. 4(4),80-93

Maryam, R.S; Ekasari, M.F; Rosidawati; Jubaedi A; Batubara, I. (2008). Mengenal Usia Lanjut dan Perawatannya. Jakarta: Salemba Medika.

Mauk, K.L. (2010). Gerontological Nursing: Competencies for Care. $2^{\text {nd }}$ edition. Canada: Jones and Bartlett Publisher.

Mitchell, A.J. (2013). Prognosis of depression in old age compared to middle age: A systemic review of comparative studies. The American Journal of Psychiatry. 162 (9): 1588-1601.

Pocklington, C. (2017). Depression in Older Adult. British Journal of Medical Practitioner. 10(1). a1007.

Riset Kesehatan Dasar (2013). Gangguan MentalEmosional. BadanPenelitiandanPengembang an Kesehatan Departemen Kesehatan RI 
Rohmawati. (2017). Hubungan InteraksiSosial Dengan Tingkat Kesepian DanDepresi Pada Lansia Di Balai PelayananSosial Tresna Werdha Unit Budi LuhurYogyakarta.

http://repository.unjaya.ac.id/2334/d iundh tanggal 22 Agustus 2019

Santrock, J.W. (2013). Perkembangan. Alihbahasa oleh: Shinto, B.A., Saragih. S. Jakarta: Erlangga.

Stewart. (2014). Buku Ajar Keperawatan Gerontik. Jakarta: EGC.

Soejono, C.H. (2006). Pedoman Pengelolaan Kesehatan Pasien Geriatri: Untuk Dokter dan Perawat. Jakarta: Balai Penerbit FK UI.

World Health Organization. (2012). Depression: a global public health concern.

https://www.who.int/mental_heal th/management/depression/who paper_depression_wfmh_2012.p df diunduh pada tgl 25 Juli 2019

World Health Organization (2017). Depression and Other Common Mental Disorder: Global Health Estimation.

https://apps.who.int/iris/bitstream /handle/10665/254610/WHOMSD-MER-2017.2-eng.pdf diunduh pada tanggal 25 Juli 2019. 